\title{
The terrifying abyss of insignificance: Marginalisation, mattering and violence between young people
}

OÑAt SOCiO-Legal SeRIES, Volume 11 Issue 5 (2021), 1222-1249: YOUTH VIOLENCE: DeESCALATION STRATEGIES AND SOCIO-LEGAL RESPONSES

DOI LINK: HTTPS://DOI.ORG/10.35295/OSLS.IISL/0000-0000-0000-1178

RECEIVED 21 OCTOBER 2019, ACCEPTED 01 SEPTEMBER 2020

\section{LUKE BILLINGHAM* \\ KEIR IRWIN-ROGERS* (D)}

\section{Abstract}

The concept of mattering can be helpful for understanding the ways in which structural and historical factors affect individual psychologies. This paper lays out the usefulness of mattering as a lens through which to examine why a small minority of young people in Britain commit violent acts. We first explore what it means to matter and the evidence linking the quest to matter with violence, and then examine the factors in contemporary Britain which can diminish a young person's sense of mattering, using recent community research. We then critique the British government's attempt to address the problem of violence through Gang Injunctions and Knife Crime Prevention Orders. We conclude by suggesting that policy-makers could gain substantial insight from investigating the connections between marginalisation, mattering and violence, rather than focusing disproportionately on the music young people choose to listen to or create, or the specific weapon that they opt to carry.

\section{Key words}

Young people; mattering; violence

\section{Resumen}

El concepto de ser importante puede ayudar a entender cómo los factores estructurales e históricos afectan a la psicología individual. Este artículo muestra la utilidad del ser importante como una lente a través de la cual se puede examinar por qué una pequeña minoría de jóvenes de Gran Bretaña cometen actos violentos. Primero, exploramos qué significa importar, y cómo queda demostrado que la búsqueda de ser

\footnotetext{
Thank you to Gordon Flett, Randol Contreras, Jamie Wintrup, Anthony Ellis, and two anonymous reviewers for very helpful comments on an earlier draft of this paper.

* Luke Billingham. Hackney Quest. Email address: luke@hackneyquest.org.uk

* Keir Irwin-Rogers. Lecturer in Criminology. Open University. Email address: Keir.IrwinRogers@open.ac.uk
} 
importante está relacionada con la violencia, y después examinamos los factores de la Gran Bretaña actual que pueden mermar el sentido de una persona joven de ser importante, para lo cual utilizamos investigaciones comunitarias recientes. A continuación, criticamos el intento del Gobierno británico de resolver el problema a través de órdenes de restricción sobre las pandillas y sobre la prevención de delitos con arma blanca. Concluimos sugiriendo que los legisladores podrían tener una mejor visión si investigaran las relaciones entre la marginalización, el sentirse importante y la violencia antes que centrarse de forma exagerada en la música que los jóvenes escuchan o crean, o el arma concreta que portan.

\section{Palabras clave}

Jóvenes; ser importante; violencia 


\section{Table of contents}

1. Introduction: Mattering, marginalisation, and violence.

2. What does it mean to matter?

3. The terrifying abyss of insignificance: Not mattering, marginality, anti-mattering, and violence.....

4. A crisis of mattering?: The factors that conspire to diminish and belittle our young people

5. Considering "violence reduction" initiatives through a lens of mattering

6. Conclusion

References 
As long as social inequality exists... The marginal will find creative, and sometimes deadly, ways to earn respect. To be somebody.

(Contreras 2013, 184)

There are young men literally dying to be someone or something, anything but no-one and nothing.

(Lee Dema, Founder of St Matthew's youth project, Brixton, London)

\section{Introduction: Mattering, marginalisation, and violence}

Too many young people feel that they don't matter, or have serious doubts that they do. A variety of factors can encourage this negative self-concept, including common forms of adolescent ontological insecurity, but it is significantly exacerbated by structural and institutional forces that can conspire to marginalise and belittle. The resultant feeling of not mattering can be deadly, for self and for others.

If we want to better understand how some young people (usually young men) become capable of physically harming themselves, it can be helpful to look at their lives through the lens of mattering. Committing acts of violence is not easy: "violence is hard" (Collins $2008,20)$. It takes significant psychosocial motivation to be able to harm the self or another. In this paper, we argue that the drive to matter can be an important component of this. The intensity and - for many - the futility of this yearning to matter is shaped by social, economic, political and cultural factors. The forces which crush an individual's sense of their worth or their power can be significant "social conditions that predictably breed violence" (Currie 2016, 89).

Investigating these connections between mattering, marginalisation and violence in the lives of young people is the focus of this paper. The paper is divided into four connected parts:

- In Part 2 we provide an overview of the literature on the concept of mattering, in order to explore what it means to matter.

- In Part 3, we focus on what it means to feel that you do not matter, and examine what the consequences of this can be, including violence.

- In Part 4, we look at the factors and forces in the contemporary world which can undermine people's sense that they matter, with a particular focus on those that affect young people (using recent community research which has amplified the concerns of young people in their own words). We examine the places and activities that some young people turn to in their quest to matter, given these adverse social conditions, including "gangs" and violence.

- In Part 5, we look at a handful of recent government schemes in Britain designed to tackle the problem of violence between young people, and highlight some of the flaws in these initiatives, by contrasting the ideas and assumptions that seem to underpin these initiatives with the insights presented in Parts 2-4 of the paper.

Applying the concept of mattering to help understand young people's actions will clearly not be any kind of panacea or silver bullet in the endeavour to reduce violence, but it could potentially help power-holders reduce the flaws and harmfulness of their policies, and help youth professionals in their day-to-day work. 
This paper therefore has a dual purpose: firstly, unpacking the links between mattering, marginalisation and violence, as a contribution to the burgeoning literature that seeks to make sense of serious violence between young people; and secondly, scrutinising government policy in light of our analysis, with a focus on the benefits that the lens of mattering can bring both to decision-making and to professional practice with young people.

\section{What does it mean to matter?}

Psychologists have defined mattering as "the perception that (...) we are a significant part of the world around us" (Elliott et al. 2004, p. 339), and as "the belief that one makes a difference in the lives of others" (Elliott et al. 2005, p. 223). As these definitions imply, there is a social and an instrumental aspect to mattering: you need to feel you are significant to others, and you need to feel you have some effect on the world. Various terms have been used to denote these two components of mattering. Flett (2018, p. 63), for instance, describes the social component of mattering as "a sense of being connected to other people" and the instrumental aspect as "a sense of agentic effectiveness". May $(1998,35)$ writes similarly of the need for both a social "sense of significance" and an instrumental "sense of power".

The need to matter in this way is fundamental to being human. Studies with babies have shown that they become utterly gleeful when they first realise that they can prompt people to change their expression, and that they can move objects - they experience what Groos (1901) called "the pleasure of being the cause" (cited in Graeber 2018, p. 83). But if infants are denied causal influence on the world in an unexpected way (if a formerly loose object is glued down, or a formerly responsive parent becomes unresponsive, for instance), this is deeply troubling to them - they can experience what Broucek (1979) called "the trauma of failed influence". This can be profoundly damaging: in René Spitz's studies of extreme neglect, he found that infants who are denied the experience of their actions causing a response from those around them literally wither away, physiologically and psychologically (cited in May 1998, p. 40). This of course reflects the well-evidenced significance of attachment in child development: as decades of research across multiple countries has shown, the nature of early relationships can have lifelong effects on our sense of who and what we are. Disordered forms of early attachment to caregivers can lead to entrenched feelings of "worthlessness" (De Zulueta 2001, p. 45); childhood maltreatment can prompt fundamental doubt about a person's mattering (Raque-Bogdan et al. 2011, Flett et al. 2016).

We have a deep-seated need to matter to other people, and to matter in the physical world - to be a consequential causal force in both a social and material sense. As Lee Dema puts it, we all want to be "someone" - a person seen as significant by others - and we all want to be "something" - an entity with some force or power in the world. The term matter in this latter sense is something of a pun on the meaning of matter in physics, where it refers to a substance which occupies physical space and has a mass: there's an analogy between the feeling of utterly not mattering, or being a "nothing", and feeling as though you do not physically exist - you are not matter.

For an individual to develop a sense of social significance, they need a secure attachment to and integration with a social group or institution, and to be conscious of being valued 
within it (Schieman and Taylor 2001, Elliott 2009, p. 37). The instrumental side of mattering has been linked to self-efficacy, the sense of control over and impact on yourself and your surroundings (Taylor and Turner 2001). As well as being temporal influenced by a person's past experiences and expectations for the future - mattering is cross-contextual, affected by self-perceived significance within different institutions such as family, school, and society more broadly (Flett 2018). As this implies, individuals can feel that they matter at different levels - to particular, identifiable others; to specific institutions; to their local community; or to their nation-state as a whole. You can feel that you matter in an immediate, interpersonal way, to particular individuals, or you can have a more structural sense of (not) mattering - you may feel structurally devalued or marginalised due to your ethnicity, gender, or sexuality, for instance. There is thus a link between a person's internal perception of how much they matter and the structural factors which affect their position or status in the social world and political economy (Flett 2018, p. 43).

The more we value a place or group or institution, the more it will affect our sense of mattering. And if we feel that we do not matter within a certain social field, it may make us more inclined to attempt emotional divestment from that field - to try to make it less emotionally significant for us. If I feel I don't matter at school, I might try, as far as possible, to reduce how much I allow school to matter to me. Different structures, groups and institutions within the complex "social ecology" (Bronfenbrenner 1979) of any young person's life will have different degrees of influence on the young person's sense of mattering, and each will have different degrees and kinds of significance for the young person. The different forms of capital that a young person holds within different social situations - economic, cultural, symbolic, and "street" capital (Bourdieu 1979, Harding 2014) - will influence the extent to which they feel that they matter within those situations. The extent to which an individual feels that they matter is thus, in part, a reflection of their perceived position within a particular group, institution, or society.

\section{The terrifying abyss of insignificance: Not mattering, marginality, anti- mattering, and violence}

His violence has evidently been stimulated by an intense desire to avoid a terrifying abyss of insignificance, indignity and humiliation. (Ellis 2016, p. 58)

I am nothing, a nobody. I always felt I was nothing, that I was not important - a nonentity. (Perpetrator of multiple homicides interviewed by Gilligan 1997, pp. 34-5)

Violence gives one a sense of counting, of mattering, of power... one must be able to feel this I-count-for-something and be able to live out that felt significance. It is the lack of this sense of significance, and the struggle for it, that underlies much violence. (May 1998, pp. 36-7)

Social non-existence is horrifying. The sensation of feeling utterly diminished and belittled, to the point that you sense you don't matter, is a psychologically devastating experience - the literature is clear on this (see Rosenberg and McCullough 1981, Schlossberg 1989, Taylor and Turner 2001, Elliott 2009, Ellis 2016, Flett 2018, Stanfield 2018). Ellis's use of the term "abyss" is well-chosen, because the dread that can accompany this profoundly troubling state of mind impinges upon our most basic existential insecurities about whether or not we are really in the world. It is striking how 
common it is in the literature on violence for perpetrators to be described as desperate to be "someone" or "somebody", and to escape the terror of being a "nobody" or "noone" (see, for instance, Vigil 1988, Gilligan 1997, Anderson 2000, Lalander and Sernhede 2011, Contreras 2013, Ellis 2016).

A wide range of studies have found that feeling you don't matter can play a significant role in complex causal chains which lead to different forms of violent acts (e.g. Marshall 2004, Elliott 2009, Elliott et al. 2011, Chiodo et al. 2012, Kruglanski et al. 2014, Jasko et al. 2016, Edwards and Neal 2017, Lewis 2017). Jasko and coauthors (2016, p. 13), for instance, conclude from their study of 1,500 violence perpetrators that "the use of violence can be in part predicted by a set of conditions that evoke a common psychological state of personal insignificance".

The concepts most commonly used in the literature to denote the opposite of mattering are "marginality" and "anti-mattering". Schlossberg's (1989) use of "marginality" is intuitive - those who experience the sense that they don't matter feel marginal, on the edges, small. The concept of anti-mattering is more sophisticated. Put forward by Flett (2018, pp. 37-44) as "qualitatively distinct" from the feeling that you matter, antimattering is a fundamentally different experience, rather than a different position on the same spectrum, involving "a sense of people being against us rather that with us" (ibid., p. 6). To return to the physical metaphor used above, if you are anti-matter, you don't just feel that you lack presence in the world, you feel an active tension with it.

Feeling that you don't matter, or that everyone is actively against you - and thus you are against them - does not guarantee violent behaviour towards others. The yearning to escape this feeling may give rise to more "pro-social" motivations, as Jasko and coauthors (2016) make clear. If it does contribute to a proclivity to violence, this may sometimes lead to violence against the self, rather than towards others: Flett (2018, p. 111) outlines the strong links that have been established between the sense of not mattering and self-harm, including suicide. Gender plays an important role here: there is some evidence to suggest that the experience of not mattering is more likely to prompt violence against others in men, and more likely to encourage self-violence or self-harm in women (May 1998, pp. 24-6, Flett 2018).

It is among men, then, that the drive to inflict harm on others can be most closely tied to the experience of not mattering, or of being "anti-matter". Committing violence can represent a desperate attempt at meaningful self-assertion in the social and physical world, or - subtly different - an attempt to escape the deadening sense of non-existence. Ethnographers have studied the specific situations that can give rise to violent behaviour in young men who are eager to escape a grinding sense of insignificance, and to assert themselves on the world. Lalander and Sernhede (2011, p. 115), for instance, argue that for the young people in their study, violence and street crime "may be interpreted as ways to dissolve the feeling of being a nobody". They focus on a 14-year-old boy called Hugo, for whom crime was "a way to feel more important and powerful". They quote him saying:

I was somebody, you get it? Cause in the beginning... I WAS nobody. I couldn't help anyone with anything, so I was nobody. But then I started to work myself up, getting some contacts, started dealing, then I became more important, you know, I started to get a higher status and then I started to like it. People looked up to you, they needed 
your help and without that help they didn't manage. (Hugo, 14, quoted in Lalander and Sernhede 2011, p. 115)

Hugo's words bear striking resemblance to the social elements of mattering put forward by Elliott and coauthors (2004): they suggest that people matter socially when others are aware of them, view them as important, and rely upon them. Hugo conveys a palpable sense of the insignificance he once felt - he felt useless, worthless, invisible. As he established himself and earnt social presence on the street, however, his social stature grew. Lalander and Sernhede (2011) make clear that violence was an important resource in Hugo's climb up the street hierarchy.

Violence can be a means to establish and assert some kind of social magnitude. As Gilligan (1997, p. 127) has argued: "[Violent men] desperately want to feel that they are big, tough, independent, self-assertive, self-reliant men, so as not to feel needy, helpless, frightened, inadequate, unskilled, incompetent". Violence can be one particularly powerful means to reduce the profoundly troubling feeling of being small, weak, vulnerable, open to violation. Vigil (1988, p. 425) explores how acting violently can be a way of "maximising the distance between feared and real identities and minimising the gap between ideal and real selves", in cases where the "feared self" is defined by weakness, insignificance and vulnerability, and the "ideal self" is defined by toughness, status and strength. Vicious self-aggrandisement can be "an assertion, sometimes a desperate one, of self, and a demand for respect and recognition" (Currie 2016, p. 60).

A common feature of violence research is an exploration of the ways in which young men who become violent resort to it as a route to achieving goals which have been made (or which seem) unobtainable through non-violent means. These goals often include personal significance and a sense of mattering, escaping the "terrifying abyss of insignificance". A number of studies have vividly conveyed the ways in which individuals' life experiences both diminish their sense of mattering and reduce their options beyond violence, leaving them to calculate, in some cases, that risking harm is better than remaining a "nobody". Gilligan (1997, p. 109), for instance, portrays this with stark eloquence: "For men who have lived for a lifetime on a diet of contempt and disdain, the temptation to gain instant respect in this [violent] way can be worth far more than the cost of going to prison, or even of dying." Currie (2016, p. 80) writes in similar terms: "[Violent men] are bred and sustained by insecurity, marginality, and the stresses of lives lived with limited resources, limited opportunities, and limited chances of dignity and respect". Research undertaken by young people in Camden (North London) who have themselves been involved in (or affected by) violence concluded that important motivations include "respect, recognition, pride, power" (Lunghy et al. 2019, p. 3), especially for those young people who "see no options" in mainstream society (ibid., p. 3). They concisely portray the link between being diminished, lacking legitimate routes to mattering, and pursing illegitimate ones: "if you are consistently looked down on you have to find your own ways to be respected or powerful" (ibid., p. 27).

The more that someone is belittled, the more they will have an elevated focus on the singular goal of reasserting their significance, even if that involves violence. Jasko and coauthors $(2016$, p. 3) found this in their study, which highlighted the strength of the need "to establish one's feeling of significance, a sense of meaning and mattering", and argued that "frustration of this need can foster a powerful experience that overshadows 
alternate pursuits and redirects individual psychological resources to the singular quest for significance". This singular quest for significance can, if other conditions are conducive to it, include violence. Gilligan (1997, p. 112) writes along the same lines: "A precondition of violence is met when these men perceive themselves as having no nonviolent means of warding off or diminishing their feelings of shame or low selfesteem (...). Violence is a 'last resort', a strategy they will use only when no other alternatives appear possible". As emphasised at the outset of this paper, violence is not easy. Physically harming another person takes all kinds of psychological drive. One thing which can fuel that drive is the deeply unbearable feeling of being insignificant, of not mattering.

If violence is so hard, why not use different means to attain a sense of significance, however limited your options are? Various writers have answered this question, often with reference to the stark scarcity of resources and of respect in some communities, which can make violence, tragically, one of the more accessible routes to mattering. Here is where socio-economic marginalisation, mattering, and violence connect. Anderson (2000, p. 68) stresses that wealthier young people have a variety of ways "to express the fact that they consider themselves worthwhile", but, in more marginalised and poorer communities, "little respect is to be had", and "the resulting craving for respect gives people thin skins and short fuses" (ibid., p. 75). Along similar lines, Ellis (2016, p. 142) writes of "fearful...marginalised men, attempting to negotiate the wreckage of the postindustrial landscape with the few resources at their disposal". Of these few resources, some men choose violence as their tool of choice for reaching a satisfactory level of selfsignificance. Lastly, Jasko and coauthors (2016, p. 14) point to certain features of violence, such as its highly visible, public character, and suggest that "due to these properties, violent means may offer a more direct route to earning significance, which may increase the attractiveness of violence to individuals searching for clear-cut and unambiguous [routes to significance]".

Some young men feel that they are "nobodies", and desperately seek resources which they can deploy to assert that they are "somebodies". No two young men will have exactly the same resources to draw upon for this - there are all kinds of social, cultural, economic, political, and technological resources that can be mobilised to help a person feel that they "count in the world", that they are socially significant, and that they have some degree of causal power and agency (as we explore in Part 4). Some young men, whose structural position in society and whose lifetime of misrecognition has left them desperate to feel that they matter, resort to "the mobilisation of one of their only resources, physical strength" (Young 1999, p. 12). Some people don't have much that they can use to assert that they are "somebodies", other than their bodies (or, of course, weapons). Many young people in this position will suffer from particular forms of shame and humiliation - connected in complex ways to their sense of (not) mattering - which make their use of violence more likely.

\section{Mattering, shame, humiliation and violence}

It seems clear from the literature that having a self-concept which involves feeling that you don't matter is closely tied with experiencing shame and humiliation. Flett (2018, p. 43) links other people's knowledge of a person's sense of not mattering with humiliation: "people who feel that their status of not mattering to anyone is publicly known will 
likely experience intense feelings of humiliation". Kruglanski and coauthors (2014, p. 74) suggest that "a loss of significance" and "humiliation" are identical or inextricably entwined experiences, by using them interchangeably. Their study also suggests a correlation between feeling shame and feeling insignificance, as well as highlighting a link between those feelings and acting violently: "[T] he degree to which [our research subjects] felt shame in the last few weeks, and the frequency of their recently feeling insignificant were (...) significantly correlated with engaging in violent actions" (Kruglanski et al. 2014, p. 83). It seems intuitive that feelings of not mattering, shame and humiliation will very commonly co-exist: feeling that you do not matter, that you do not "count in the world", is likely to be accompanied by intense shame and humiliation. Ellis (2016, p. 110) alludes to this by writing of "shame-inducing marginality". For explanatory purposes, it can be helpful to analytically distinguish between a person's self-concept - their understanding of themselves and their position in society - and the emotional ramifications that this will have for them (though in reality the two may well feel, and be, inseparable.) The research seems to suggest that a self-concept which includes a sense of not mattering is likely to induce emotions of shame and humiliation.

Gilligan's (1997) abiding thesis is that, among all of the violent men he ever worked with clinically, shame was always a significant feature of their emotional lives, and always seemed causally connected to their violence. He writes at length about the marginalising and diminishing lives that these men have lived, again suggesting a link between the experience of not mattering and this dangerous sense of shame and humiliation. ${ }^{1}$ The causal link that he establishes between these particularly painful emotions and the perpetration of violent acts has been substantiated by a large number of other studies and ethnographies. Given the connection between mattering and shame, then whatever the precise nature of that connection - this adds weight to the argument that the sense of not mattering can make violence more likely. In his detailed portrayal of the life of "Darren", Ellis (2016, p. 41) places great significance on his experience of humiliation. He writes that Darren had a "painfully humiliating encounter" which contributed to a "transformation within him": "As Darren explained himself, he was "a nobody", but in the aftermath of this event he emerged from its shadow determined to become "somebody" (Ellis 2016, p. 41). Darren's humiliation left him desperately, dangerously eager to assert his social magnitude. In a similarly rich account of another young man's violence, Harris (2017, p. 527) writes that "Daniel" adopts "a veneer of selfsufficiency to mask and defend against intolerable feelings of terror, shame and envy (...). Real or perceived slights gave rise to him unleashing his anger and hostility on those nearest to him who threatened to harm his fragile state". Feeling shamefully insignificant can cause an aggressive, unpredictable brittleness.

\footnotetext{
${ }^{1}$ Like many writers, Gilligan (1997) tends to use "shame" and "humiliation" interchangeably. Gaskell (2005), interestingly, opts to use a hyphenated compound of the two: "shame-humiliation". Katz (1990) argues that they are different, suggesting that shame can come from within ("I'm ashamed of myself") and so possesses some potential utility in regulating behaviour towards others, as well as without ("they have shamed me"). Humiliation, on the other hand, has no potential social function and is purely destructive, with no means of affecting the individual's behaviour in a more positive sense. Ellis similarly holds that humiliation is a more damaging experience, suggesting that most of the men he has interviewed and encountered in research are deeply humiliated, leading to destructive cycles of "retaliatory" violence (private correspondence).
} 
The humiliation experienced by young men such as Darren and Daniel can come in different forms. As explored later in this paper, there are all kinds of diminishing pressures in contemporary society which can conspire to humiliatingly undermine an individual's sense of mattering, and this is particularly true of young people growing up in marginalised communities. Ellis (2016) points to a few different sources of humiliation and shame, such as coming off the worst in a fight, moving to a new area in which you are utterly unknown and insignificant, and the "potentially cumulative (...) traumatic experiences scattered throughout a biography" (Ellis 2016, p. 91). The most devastating form, though, he suggests, is the "persecutory humiliation associated with having been dominated" (ibid., p. 102). Feeling that you are at the whim of another - that they have complete power over you, and you have none over them - can bring a very palpable sense of not mattering. You are impotent and causally insignificant, a puppet on their string. Ellis suggests that any experience of this nature causes deep, humiliating scars, which can make it more likely for a young man to want to inflict just the same kind of domination on another.

\section{The role of mattering in the microsociology of violence}

Asserting yourself violently over another can deliver an intoxicating feeling of significance and power. There is a "sense of power and mastery inherent in dominant interpersonal behaviour" (Flett 2018, p. 64). Violently dominating another person can give you a palpable sense of your causal power: you are a potent, agentic being who can make things happen, even against another's will. And it can also enhance your sense of social significance: there, in the moment, you may directly experience your reputation growing, if there is an audience (see Collins 2008, p. 369), or, even if not, you may still have a slightly dimmer sense that, when word gets round, this successful act of violence will inflate your social stature in your neighbourhood.

Whether committing violence on a purely individual basis or as part of a (semi)organised group, you can achieve "a swelled sense of pride and power by having dominion over others"; a vicious escape from "personal insignificance and worthlessness" (Gilligan 1997, pp. 182-3). The enjoyment of victorious violence has long been observed. Jouvenel wrote in the early 1900s that "a man feels himself more of a man when he is imposing himself and making others the instruments of his will" - it gives him "incomparable pleasure" (quoted in Arendt 1970, p. 36). As this implies, the form of pleasure prompted by this experience is clearly gendered. Contreras (2013, p. 168) makes the point that the emotions which drive violent acts in the moment are "informed and sustained" by "race, class and gender". Contreras's friend Neno describes how he feels when committing violent acts: "you feel a lot of power (...) you're the one telling them what to do...controlling what happens" (ibid., p. 162). Neno clearly feels some of that "incomparable pleasure" which Jouvenel wrote of. This sense of mastery is so invigorating for Neno because he lacks it in most other areas of his life. As Gilligan (1997, p. 132) observes of men who control their wives violently: "their desire for omnipotence is in direct proportion to their feeling of impotence". When Contreras's friends begin to conduct violent drug robberies, he says "they recuperated their social losses and controlled their crisis-ridden lives. They were 'somebody' in one more way" (Contreras 2013, p. 142). Within both individual acts of viciousness and within their lives in a wider sense, violence gave them an enhanced sense of efficacy and control. When describing 
how the robberies take place, it is clear that Contreras's friends have absolute control over the men they are stealing from: they are clay in their hands, utterly malleable. If, in normal life, the world feels completely impervious to your influence, being able to assert yourself on another in this way, and have them forcibly attend to your every whim, can bring a revivifying sense of potency. To the wealthy and powerful, the world tends to be malleable anyway: they can go where they want to, eat what they want to, hire and fire who they want to, create new products using their extensive capital, dominate other people. To the marginalised, the world can feel stubbornly immutable, immune to their influence, infinitely bigger than them. Violence can be a way of shattering this impotence, giving its perpetrator a tangible sense of causal power.

Violence can also be a means to achieve the second main aspect of mattering: social significance. Lewis (2017) found this in her study of young men who had become violent in their teenaged years. She writes that there is "no greater threat than failing to matter", and that violence can be a way of young men "compelling someone to care for them" (Lewis 2017, pp. 1319, 1327). They make themselves "a matter for concern" through violent acts (ibid., p. 1328). Having never felt that they mattered, through their violence they assert themselves on others, forcing them to care about their existence, even if only in a negative way as "anti-matter". If Lewis conveys a desperate attempt on the part of these young people to gain just a semblance of mattering, Collins (2008) gives us a vivid portrayal of the great gains in social magnitude that can accrue to those who skilfully execute violence. When there is an audience observing the violence, they form a "reputational goldfish bowl" (Collins 2008, p. 369), and even those whose violence is enacted alone, like hitmen, can enjoy a "special kind of reputational pride", the "prestige of pure violent competence" (ibid., p. 439). A hitman might seem to be a solitary being, but "he is operating in a social community whose respect he cares about" (ibid., p. 440). Violence is always a deeply social act, then, in the sense that its enactment will both reflect and affect the social significance of the combatants. Violence can be a powerful means to matter.

\section{A crisis of mattering?: The factors that conspire to diminish and belittle our young people}

There are a wide range of different cultural, social, economic and political phenomena which can encourage a heightened experience of anti-mattering or marginality in substantial proportions of modern societies. To give a flavour of this, we have given some examples in the diagram below, which summarises different dimensions of what could be called a "crisis of mattering" (see also Billingham and Irwin-Rogers 2020). 


\section{TABLE 1}

\section{ECONOMIC}

Processes which may undermine mattering:

Globalisation, gentrification, increasing inequality, myth of meritocracy, "de-socialised capitalism"

Example:

In vastly unequal societies, money can become the measure of a person - cultures "lionise wealth" (Dorling 2018, 249). As Marx put it almost two centuries ago: "I am a wicked, dishonest man... but my money is honoured so also is its possessor" (Marx 1844/2000, 118). In a wealth-obsessed world, those with very little can feel an intractable sense of insignificance. This is exacerbated by the myth of meritocracy, which suggests that wealth the most extreme forms of economic difference between agents in our society are due to completely accidental factors, such as being born the child of someone who is wealthy, or being accidentally at the right place in the market at the right time" (Geuss 2016, 182). Our economic reality barely approximates anything like meritocracy it's more "a veritable chaos of reward" (Young 1999, 152). But the cultural suggestion that money matches merit can leave those who receive very little reward feeling systematically belittled.

\section{POLITICAL}

Processes which may undermine mattering:

Depoliticisation, disenfranchisement,

privatisation, post-democracy

\section{Example:}

To matter politically, you have to feel that powerholders are responsive to you, and that there is a possibility of participating in political decisionmaking, should you so wish. Streeck (2014) argues that processes of privatisation have left decisionmakers in many contemporary nation-states more responsive to the markets (the Marktvolk) than to the citizenry (the Staatvolk), and thus, the latter group may feel a reduced sense of mattering. Leys (2003) writes similarly of "market-driven" politics - we, the people, are in the passenger seat at best. For this and other reasons, Crouch (2004) has argued that we live in "post-democracy", because our pseudo-democratic political participation no longer matters; it no longer has any significant causal power in the world. As individual people and as a collective of citizens, then, our political mattering has been reduced. distribution is fair, despite the fact that "most of

\section{SOCIAL-TECHNOLOGICAL}

Processes which may undermine mattering:

Globalisation, proliferation of social media

Example:

Mishra $(2018,339)$ writes with characteristic verve of how globalisation now means that "the individual confronts a new indecipherable whole: the globe $(. .$.$) the individual can act satisfactorily$ neither upon himself [sic] nor upon the world, and is reminded frequently and humiliatingly of his limited everyday consciousness and meagre individual power". Feelings of insignificance or invisibility can be exacerbated if a person is frequently observing others on social media who "are seemingly surrounded by other people who value interacting with them" (Flett 2018, 107). What some young people call "clout" is a particularly addictive form of online social magnitude, the gain or loss of which can have high emotional stakes. Social media can be a vehicle through which young people assert their magnitude to both expressive and instrumental ends, and this has been a trend observed among those involved in criminal activity (Storrod and Densley 2017, Irwin-Rogers 2019; see also Lauger and Densley 2018, Lane 2019).

\section{CULTURAL}

Processes which may undermine mattering:

Postmodernisation, cultural fragmentation and contestation, secularisation

\section{Examples}

In a heavily contested cultural world, the victim of racism and the "identitarian" racist can both claim to suffer from misrecognition and marginalisation, with very different political ramifications. The far-right identitarian movement is based on the vertiginous feeling among some white men that their cultural power is diminishing, resulting in a sense of "imminent existential threat" (Ebner 2019). These men feel they are losing their cultural significance and power. Secularisation, another contentious cultural trend in contemporary Western societies, might undermine mattering as religion can fulfil the need to "find meaning and hope, to combat one's insignificance", and can "give a sense of power and effectiveness through association with an all-powerful being" (Schumaker 1997, 202, 195).

Table 1. Some dimensions of the "crisis of mattering" in contemporary society.

If there is a contemporary crisis of mattering, it clearly has uneven effects on different people in different places at different times. And the extent to which all of these various marginalising processes will result in an individual or group experiencing a sense of crisis is obviously subjective, as the example of the Identitarian movement illustrates: 
there may be some basis for some of their claims of disempowerment, or it may just be that their perception of cultural reality isn't matching up to their "fantasies of a powerful, respected, narcissistic idealised self"' (Ellis 2016, p. 143).

\section{If there is a "crisis of mattering", there's reason to believe it's worst among the young}

There are grounds for reasoning that young people may be particularly vulnerable to experiencing crises of mattering. As Vigil (1988, p. 430) puts it, the teenaged years are "generally a transitional, marginal period" which can be difficult to navigate socially and existentially. A wider crisis of mattering in society - a crisis of what it means to matter, and how you can go about establishing yourself as someone who matters - will be something that young people are especially, painfully conscious of, as they seek out sources of mattering in and for their individual lives.

There is evidence that a large proportion of young people really do struggle to develop a sense of mattering, and it is possible to identify specific social, economic, cultural and political factors which can seem to make the quest to matter a more difficult and complicated endeavour for young people. There is a substantial research base, from North America at least, suggesting that the sense of not mattering is alarmingly common among young people: Flett (2018, p. 297) cites numerous, large-scale studies which suggest that up to $50 \%$ of young people in various parts of the US and Canada do not feel that they matter to their communities, and around a third don't feel they matter to other people. He concludes that "feelings of not mattering are far too prevalent among adolescents" (ibid.), and suggests that the rise in mental health issues among young people could well be linked to this (ibid., p. 111).

We are not aware of similar, large-scale research being undertaken in the UK, but there are clear indications that many young people in Britain may experience forms of marginality or anti-mattering which in some way reflect the reality of their interpersonal, institutional, or societal situation. As Kruglanski and coauthors (2014, p. 75) point out, "individual significance loss" can have any number of causes, and "can be the result of general, economic, social, and political conditions" as much as the result of particular interpersonal events (Kruglanski et al. 2014, p. 75). In his recent book The Crisis for Young People, Green (2017) suggests that conditions are profoundly troubling for young people in contemporary Britain, arguing that they suffer from significant generational inequalities in education, work, housing and welfare.

A range of recent studies in London have garnered the perspectives of young people directly on these issues, helping to convey the ways in which these adverse social conditions can diminish the sense of mattering. Schools can seem to disproportionately punish those students "who are valued less" (Lunghy et al. 2019, p. 21), or may contain no adult that a student would feel comfortable to speak with, even if they were experiencing extreme distress (Billingham 2018). Some young people are of course excluded from school entirely, and a few get lost from the education system altogether (Gill et al. 2017). Jobs available to young people are often "unrewarding, low-paid and boring" (Lunghy et al. 2019, p. 25), and many don't feel that they're given a chance by employers at all (Billingham 2018). This problem, alongside rising housing costs, mean that many don't feel they'll be able to stay in the neighbourhood they call home (Blazey 
et al. 2017, p. 5; Billingham 2018, p. 56). Even if able to remain in their community, some experience what Butcher and Dickens (2016, p. 800) call "affective displacement": an undermined sense of belonging due to feeling progressively displaced by other, wealthier demographic groups. This feeling was expressed in Billingham's (2018, p. 56) study in North East London: young people reported that they "don't belong any more", that "the area is not really ours anymore", and that "Hackney is no longer the Hackney I grew up in". Related to this can be a profound sense of political disempowerment: "they kinda are leaving us behind (...) a lot of people are being left behind, if you're not rich, if you're not middle class or above that, the government ain't really helping you"; "in order for the government to actually listen, or for them to realise that this is getting out of hand, another riot needs to happen. It sounds so bad to say, but... it's getting worse and worse every day... no-one has a say any more... nothing's getting done" (Billingham 2018, pp. 56-57). These young people certainly lack any sense of mattering in the political world, or of "making a difference in the broader scheme of sociopolitical events" (Fromm 1941, quoted in Flett 2018, p. 38).

These young people's experiences are related to wider socio-historical events of the past few decades, which have affected the structural determinants of their lives. Many young people are experiencing what Vigil and Yun (1998) call "multiple marginality"2 marginalisation across many different aspects of their lives, occurring in different ways at different times in different places. On an institutional level, in their schools, many students are affected by the national process of academisation, and they are feeling the influence of seemingly concomitant disciplinary punitiveness. In terms of their economic position, Winlow and Hall (2013, p. 143) vividly convey the kind of economic marginality experienced by some young people growing up in impoverished areas, which they argue is "deeply indicative of a capitalist labour market that no longer has any direct and immediate need for these populations".

Those young adults who are forced to seek welfare support when out of work are made to undergo the "various degradation rituals" that have become an inherent feature of the "workfare" regime in austerity Britain (Bond and Hallsworth 2017, p. 75). Especially for those whose self-identity is significantly invested in meaningful employment, this kind of economic anti-mattering can be deeply humiliating. There are few more diminishing experiences than being "cast adrift; a discarded irrelevance" (Young 1999, p. 12). Many young people are growing up in families on marginalised housing estates "where capital originally led them, then left them stranded as it winged its way elsewhere" (ibid., pp. 20,50). Markets of all kinds "can always do without them" (Streeck 2016, p. 112). The proportion of British society affected by this chronic and pernicious form of economic exclusion is not small - Dorling (2018, p. 182) estimates that over a quarter of households are so poor that they are "unable to take part in the norms of society". Even prior to the turn of the millennium, Young (1999, p. 94) observed "the most extraordinary crisis of identity and self-worth" among those he called "lower class

\footnotetext{
${ }^{2}$ It's perhaps an indication of how little attention mattering has received within the criminological literature that Vigil and Yun (1998) do not cite Schlossberg's (1989) definition of "marginality" (as the opposite of "mattering") in his work. The same is true of Wacquant (2007), in his use of the concept of "advanced marginality".
} 
youth". There are sufficient grounds for suspecting that this crisis has become more acute since then.

A fascinating study (Gaskell 2005) based on research with young people in East London drew direct links between their sense of political insignificance and the violence that occurred between them. It concludes that "many young people [in East London] understand their experiences of violence and victimisation as being shaped by their reduced citizen status" (Gaskell 2005, p. 1). From extensive conversation and a range of workshop activities with a group of teenaged young people, Gaskell found that

violence and victimisation [were] understood as a symptom of a disrespected citizenship relationship with the state (...). Young people who experience their relationship with the state to be disrespectful can begin to seek out alternative routes to gain respect; one such way was identified as an engagement in violent behaviours. (Gaskell 2005, p. 1)

These young people felt politically invisible, ignored, insignificant, and felt that the violence in their community was a symptom of others in their generation seeking respect, social magnitude, significance. And, vitally, it's not just their age that creates their feeling of political powerlessness:

They consider their young age to be just one important factor in their 'less than' citizenship status. Young people consider themselves to be excluded from and therefore a disrespected part of society... [as a result] they begin to reject the 'conventional norms' of citizenship and subvert these (...). Many young people then attempt to gain respect through other channels: channels that have greater meaning within young people's lives. (Gaskell 2005, p. 203)

These channels include bullying, "gang" affiliation and violence. Gaskell's work raises an important question: when facing adverse social and economic conditions, where, and to whom, can young people matter?

\section{Where do young people matter?}

To children like these the world could be a cold, empty place, but in the lodging houses they were always welcomed (...) for the first time in their lives they were listened to, and the more crimes they could quote, the better would be their reception. (Duckworth 2002, p. 34)

It would do us good to consider where our young people feel that they matter. Duckworth writes of Victorian lodging houses as dens of iniquity occupied by children and young people cast adrift from society. ${ }^{3}$ But for a moment, she views them through the eyes of their residents, and conveys the value that young people felt they had in these places - a value they had never felt elsewhere. For the first time in their lives, they are welcomed and listened to. She writes that these children had been "wholly uncared for by family, church or state" (Duckworth 2002, ix). Those of us who work with young people all know some who have experienced their families, their schools, all of the institutions in their lives, as cold, empty places, in which they are wholly uncared for. And we all know young people who first experienced that intoxicating sense that they

\footnotetext{
3 There's no exact equivalent of the "lodging house" in contemporary Britain, though the worst kinds of hostels and Pupil Referral Units have some characteristics which make them somewhat comparable.
} 
might really matter to someone, or to something, in places where illegal activities including violence - are narrated with pride.

Some institutions excel in their capacity to diminish young people, resulting in an understandable tendency on the part of those young people to emotionally divest from them. Unfortunately, some schools prove themselves adept at alienating their pupils, through techniques of degradation and humiliation that lend themselves to comparison with practices in the criminal justice system. Internal exclusion practices such as "isolation booths" led young people in Barker and coauthors' (2010) study of a school in Britain to compare it to a prison, for instance. In his study in the States, Anderson (2000, p. 94) wrote of schools "losing ground" to young people who had become enamoured to a "street orientation": these students were emotionally detaching themselves from the school, in tandem with their growing attachment to the street. Anderson makes clear that there are multiple factors involved in encouraging both this detachment and attachment - it is of course not as simple as the schools just pushing the students away, but there is a suggestion that some students felt more "welcome" among peers on the street. This is certainly the case for "Osman", a student featured in Kulz's (2017) ethnography of one inner London school, who experienced education as an "increasingly antagonistic landscape where [he] lacked value".

The world of work can be another institution which undermines, rather than builds up, a young person's sense of mattering. Currie (2016, p. 61) describes the deeply belittling effects of what he calls "marginal work", and emphasises the significant influence this can have on young men's sense of themselves, given the importance of "our place, or lack of one, in the world of productive work". Ellis (2016, pp. 27-8) gives us a sense of what the marginal work undertaken by many young people looks like: "expendable, low-paid, menial, with a determinate contract length, de-unionised and vulnerable to the whims of a mutative post-industrial economy that may suddenly render them obsolete in the name of 'efficiency' or 'cost-effectiveness'". In their community research in East London, Community Links (2019, p. 17) identified that young people felt "intensely disconnected and excluded from their wider communities", leading to "a refusal to engage with local institutions". A wider sense of disconnection and alienation meant that local institutions would never be significant to them.

If we track where and to whom a young person goes if their family and their school matters increasingly little to them, we are led with some doom-laden inevitability into that most murky of criminological grounds: "gangs". This shouldn't be inevitable, of course, either in real life or in criminology - it would be a wonderful thing if more young people could find a sense of mattering in different kinds of "third institution" (aside from the compulsory ones - family and school), such as youth centres, sports clubs, music groups, or faith organisations; and it would be equally welcome if there were as many criminologists investigating the psychosocial benefits of these places as there are exploring every discernible feature of criminal "gangs" (see Harding 2014, pp. 21-42 for a helpful summary of what he calls the "academic ganglands"). Though there are good reasons to doubt the helpfulness of the concept of "gangs" (see, for instance, Sullivan 2005), for our purposes here it is worth a brief exploration of what young people can gain from membership of (semi-)organised street-based peer groups, to provide another 
example of how helpful the concept of mattering can be for understanding young people's lives and choices.

Gangs can be places in which young people matter more than they do in the other institutions of their lives. Vigil (1988, p. 421) provides an especially vivid account of this, arguing that a gang can be an incredibly effective "competitor" for young people's emotional investment, as compared to their family or their school. They can become a highly significant place for young people, which can meet their psychosocial needs in a way that more formal institutions cannot. Thus, the gang "becomes a substitute for the many caretakers who have failed" (ibid., p. 432). Osman, the student mentioned above who appears in Kulz's (2017) study, found this: "his [gang] identity became a more amenable, plausible source of value [than school]... despite the real dangers, his 'family' [gang affiliates] offer him recognition". Vigil (1988, p. 422) suggests that a strong correlation can be found between gang involvement and the extent of a person's multiple marginality, asserting that gang involvement can usually be predicted by "how severe and deep-rooted the effects of racial and cultural discrimination and poverty have been on an individual, or how family and school authorities have failed to influence and guide". Those who end up involved in gangs are disproportionately from "marginal, unstable economic conditions" and "poorer homes" (ibid., p. 426). Having "lamented that they were "nobody' before", gangs can be a "crucial haven" (ibid., 428, p. 427). In their much more recent research, Community Links observed a similar phenomenon in East London: deeply marginalised young people are given "a sense of belonging and purpose by gangs", which form "a kind of alternative community, offering a sense of stability and belonging missing from their own lives" (Community Links 2019, p. 17).

When different young people have been asked to give their reasons for joining a gang, their answers of course vary, but some idea of mattering is often apparent. A gang member from downtown Los Angeles interviewed by Vigil (1988, p. 427) gave a few reasons: "it was either get your ass kicked every day or join a gang and get your ass kicked occasionally by rival gangs. Besides, it was fun and I belonged". Gaskell (2005) spoke with a number of young people in East London aged between 13 and 16 about why joining a gang was appealing, and it's worth listing some of their responses:

- 'To be respected from other people and to make other people fear' (ibid., p. 132) ;

- 'People in gangs, they act tough, so people know who's boss! I think [gangs] seem interesting, fun and you feel wanted' (ibid., p. 216)

- 'You get lots more friends, it's cool, you're accepted and you get respect' (ibid., p. 229).

In her analysis, Gaskell argues that "gangs represent social networks whereby power, respect and status can be negotiated (...) [they] fulfil the need to feel wanted, to have oneself validated through the acceptance of others" (Gaskell 2005, pp. 132, 216). Clearly, gangs are a place where young people can feel socially significant. Interestingly, Gaskell suggests a close conceptual link between shame and respect: "Respect derives from the primary emotion shame in that it has been understood, interpreted and can therefore be (re)articulated by young people themselves as (dis)respect" (ibid., p. 154). Young people are familiar with respect and it is a term with rich significance for them, and this may, on a deeper level, also reflect the intense, inverse importance of shame. 
Gangs come in all different shapes and sizes, and many are characterised "more by mischief than malice" (Vigil 1988, p. 422), or more by friendship than fighting, but there of course some (semi-)organised groups of street-based young people who engage in criminality and violence - these can be places in which violence really matters, and in which the quest to matter will always involve violence. In some cases, gangs are places where "young people have a continuous opportunity to prove their worth and make their claims for respect, through violent actions" (Gaskell 2005, p. 216). Violence can be an important "gang thing", Vigil (1988) argues, and "it is by doing these 'gang' things that earn you the respect and recognition as a dependable gang member with huevos (balls)" (Vigil 1988, p. 432). Kruglanski and his team suggest the process by which an individual feeling of not mattering could result in violence, via membership of a violent group:

If personal loss of significance invites a collectivistic shift - which in conditions of intergroup conflict may encourage individuals to fight against the group's enemies suffering a loss of significance should augment the tendency to fight. (Kruglanski et al. 2014, p. 83)

We do not wish to suggest that the "quest for significance" is the only factor, or even necessarily the most important factor, pulling some young people into "gang" activity. As this brief account of a small part of the literature clearly conveys, some young people certainly are attracted to informal groups of peers in part because they lack a sense of mattering elsewhere, and feel (perhaps rightly) that they can gain a greater feeling of mattering through affiliation with the group, but the dynamics of gang involvement are obviously far more complicated than this. Aside from anything else, we wouldn't want to suggest that gang life is some simplistically enjoyable experience (Vigil 1988, p. 432, cites a young person complaining that "you can't even have a wedding dance without someone getting hurt"), and of course many young people are drawn in more through exploitation than enthusiasm (Irwin-Rogers et al. 2019). ${ }^{4}$ But it still seems important to ask: how did Britain get to a position in which, for some young people, the embrace of a gang seems warmer, more meaningful, more significant, than what they can find in any other institution of their lives?

\section{Considering "violence reduction" initiatives through a lens of mattering}

If mattering offers a useful lens for making sense of violence between young people, to what extent do current initiatives purportedly aimed at reducing violence accord with the insights that this lens reveals? We will briefly consider two contemporary UK Government responses to serious violence: Gang Injunctions and Knife Crime Prevention Orders (KCPOs).

Gang injunctions were made available in the UK following the enactment of the Policing and Crime Act 2009. Section 34 of the Act enables law enforcement agencies to subject a young person to a Gang Injunction if they can prove to a court, on the balance of probabilities, that:

\footnotetext{
4 There are of course a wide variety of reasons why a young person may be vulnerable to exploitation, and a lack of mattering is certainly one of them, but we wouldn't want to overstate its importance in this regard.
} 
- An individual has engaged in or has encouraged or assisted gang-related violence or gang-related drug-dealing activity; and

- It is necessary to grant the injunction to prevent an individual from engaging in, or encouraging or assisting, gang-related violence or gang-related drugdealing activity and/or to protect an individual from gang-related violence or gang-related drug-dealing activity.

The scope and nature of the prohibitions and requirements that can be imposed on a young person subject to an injunction are vast and intrusive. For example, Section 35 stipulates that an injunction can prohibit a young person from "being with particular persons" (e.g. their friends), from "being in a particular place", and from "wearing particular descriptions of articles of clothing". Section 36 specifies that the prohibitions and requirements made as part of Gang Injunctions can last up to a maximum of two years.

How might these Gang Injunctions look from the perspective of young people allegedly involved in gangs? Recall that the feeling of "anti-mattering" can involve the perception that other individuals, groups or institutions are actively against you. Are gang injunctions likely to ameliorate this perception or exacerbate it? First, note that the burden of proof for imposing a Gang Injunction is not "beyond all reasonable doubt" as with a criminal offence, but "on the balance of probabilities" - a much lower threshold to satisfy. In other words, young people have much less protection against a Gang Injunction being imposed on them than a "non-gang" member of public has in the case of a criminal conviction. Therefore, it is likely that - on the balance of probabilities some of these orders will restrict the freedoms of innocent young people who had not, in fact, engaged in or encouraged gang violence. While the orders themselves do not constitute criminal convictions, the young people subjected to them might nevertheless subsequently be convicted of a criminal offence and imprisoned if they partake in everyday activities that do not ordinarily constitute violations of the criminal law, for example, seeing certain friends, being in certain places, and wearing certain clothes. Their freedom of association and of action - and with them their sources of social significance and agency - can be severely diminished.

There are good reasons for the requirement to establish that a person has committed a criminal offence "beyond reasonable doubt" given that the consequences of being found guilty of a crime can be severe. In order to avoid the perception that the state might be acting against our interests - in other words, that the state is here to protect and serve us, rather than attack and oppress us - we rightly demand that state institutions prove beyond all reasonable doubt that we have broken a law before being punished. It seems reasonable to assume that young people accused of being part of a gang will feel aggrieved that severe prohibitions and requirements can be imposed on their lives following a mere balance of probabilities judgement. This is all the more likely when we consider the nature of the potential prohibitions, for example, preventing young people from seeing their friends, who, in many cases, may provide one of only a very small number of sources of mattering in these young people's lives.

For those who are gang-affiliated and receive one of these injunctions, it's worth considering both the immediate and longer-term consequences. There is a chance that, in the immediate term, an injunction of this kind may reduce the likelihood of them 
perpetrating or becoming the victim of violence (Carr et al. 2017). But, as with many punitive measures, immediate term efficacy (if there is any) can be far outweighed by counter-productivity in the longer term. As outlined above, it is illuminating to consider where a young person matters - where and to whom they feel significant and valued, and how they forge their identity as a result. The inverse of this is also true: it is important to consider where and in which circumstances young people feel powerless, marginalised, alienated. If a gang-affiliated young person receives a Gang Injunction, it seems likely that it will - on the balance of probabilities, again - deepen their sense of anti-mattering with regard to officialdom. ${ }^{5}$ It will exacerbate their sense that authorities and institutions are against them, and reinforce the idea that their only hope of positive significance is by associating with those who are in opposition to those forces; those who, significantly, may not even know and are very unlikely to use their legal name (or "gov" - the shortening many young people use to refer to their "government name"). There can be considerable doubts, then, about both the efficacy and reasonableness of Gang Injunctions, given the effects they can have on both innocent and guilty parties.

A similar argument can be made in the case of Knife Crime Prevention Orders (KCPOs). KCPOs bear many similarities to the Gang Injunction, albeit they are targeted specifically at knife possession and knife crime rather than "gang crime" per se. In a purported attempt to address the increasing prevalence of knife crime in the UK, the Government inserted amendments into the Offensive Weapons Bill in February 2019 that provides the legislative framework for KCPOs. The orders can be imposed on anyone over the age of 12, if (again on the balance of probabilities) the person in question was deemed to be in possession of a bladed article in a public place without good reason, on at least two occasions.

The language used in the Offensive Weapons Bill leaves open a wide degree of discretion in interpretation: one potential condition of KCPOs, for example, prohibits a young person from "using the internet to encourage crime involving bladed articles" - but what precisely constitutes encouragement? Recent police priorities indicate that this condition has likely been designed to target the increasingly popular genre of rap music known as "drill", which involves, among other things, young people rapping about serious violence in the areas in which they live (for further details see Lynes et al. 2020). To what extent, however, does rapping about violence further encourage it? While this is a difficult empirical question to answer, it is clear that the perception of many young people is that drill does not encourage violence, but simply reflects the serious violence already present in young people's lives (Irwin-Rogers et al. 2020). Thousands of drill music tracks are produced and uploaded to internet platforms such as YouTube and Soundcloud every month, with preliminary research suggesting "there is no meaningful relationship between drill music and real-life violence" (Kleinberg and McFarlane 2020). For many young people, producing drill music is one of very few viable and meaningful routes to feeling like a significant part of the world around them (see Thapar 2019). Creating, performing and disseminating music enables many young people to connect

\footnotetext{
5 The message from authority to certain young people that they are "officially" gang members, through Gang Injunctions, could also deepen their attachment to gang identity, if they heighten the individual's notoriety in a manner which boosts their reputation in "gang circles". Whilst casting them ever-more aside from "legitimate society", Injunctions could therefore increase the extent to which a young person values their gang affiliation, and emotionally invests in mattering to their "gang".
} 
to their closest and extended peer groups, feel part of a community, receive peer affirmation, and it can provide a sense of agentic effectiveness that might otherwise be sorely lacking in their lives.

In short, therefore, one of the consequences of Gang Injunctions and KCPOs is that these suppression and enforcement based "violence reduction" initiatives are likely to further erode many young people's sense that they matter. The process by which they are imposed exposes young people to severe incursions on their liberty, based on a reduced burden of proof relative to that associated with the criminal law. It is reasonable to assume that this is likely to intensify feelings on the part of many young people that state authorities are against them, and thus push them further away from legitimate means of achieving a positive sense of social significance and agency. Second, the substantive content of Gang Injunctions and KCPOs, which include a wide array of requirements and prohibitions that curtail young people's freedoms, strikes at the heart of some of the interpersonal relationships and social activities that help young people develop a sense that they matter. At worst, these initiatives could substantially increase young people's sense of anti-mattering. If this occurs, far from being considered violence-reducing, these initiatives - whatever their immediate effects - could serve in the longer-term to increase serious interpersonal violence among an already highly vulnerable and marginalised group of young people in society.

\section{Conclusion}

Rigorously investigating the social, economic, political, cultural and psychological determinants of serious violence between young people provides the only opportunity to significantly reduce its perpetration in a long-term and sustainable manner. We would like to suggest that those policy-makers who focus more on drill music than disadvantage should seek to understand and address the causes of violence, rather than obsessing over its soundtrack. To this end, we think that people with a stake in this issue could gain substantial insight by examining violence through the lens of mattering.

Investigating the factors that affect young people's sense of mattering forces us to consider how our political economy and institutions form young people's selfperception and constrain their life choices - it compels us to examine the "adverse social conditions that predictably breed violence" (Currie 2016, p. 89). It encourages us to consider each young person's past, present, and future: the trauma in their past which structures their emotions, their current treatment in the education system or job market, their sense of the future. If a young person is given no reason to believe that they matter to their family, their school, their workplace, their community, the economy, or "society" more broadly, we should not be surprised if they seek alternative means of mattering, which can, in some cases, involve physically harming themselves or others. The denigration and insecurity that can prompt some young people's violent quest for mattering should be our focus, not the music they make along the way or the particular weapon they choose to carry.

People commit serious and sometimes fatal acts of violence against themselves and others to avoid social death (Gilligan 1997). Indeed, one young person that Billingham works with on youth projects in London once said that some young people died long before they were killed: they were living their lives in full acceptance that their actions 
and associations raised their risk of serious and potentially fatal injury, but they didn't fear it, because they were, in a sense, already dead - they lacked the hope, vitality and self-worth which defines life. We need to interrogate how and why this can happen in a society as supposedly advanced, wealthy and healthy as the UK in the Twenty-First Century.

The lens of mattering that we promote in this article is certainly not intended to pathologize individuals, or to focus people's attention myopically on individual psychology. Instead, we intend it to foreground the structural factors that shape individuals' sense of their significance and value in the world around them, while offering a means by which these structures can be connected to attitudes and behaviours at the level of the individual. Our central argument is that we should strive towards building societies that help young people to develop a sense that they genuinely matter, and that only by doing so are we likely to see a significant decline in the levels of serious violence that currently blight the lives of far too many young people. We need adults, agencies, services, institutions and authorities to provide an environment in which young people can develop a healthy sense of their significance and their agency (and this has to start with the early years - see Irwin-Rogers et al. 2020). Government initiatives such as Gang Injunction orders and Knife Crime Prevention Orders are directly antithetical to this, and seem likely to deepen a young person's sense of diminishment, resentment, shame and anti-mattering, as well as encouraging or exacerbating anti-authority sentiment - a dangerous collection of feelings, given the weight of evidence connecting them with violence.

Violence between young people is not the biggest cause of harm in our society, by any measure, but it has desperately tragic consequences for those involved. It very often reflects the concentration of harm and humiliation in particular places at particular times. In contemporary Britain, some neighbourhoods contain "an extremely inflammable mixture" of harmful and belittling structures, institutions and authorities, which at worst give rise to "slow riots" among a "permanently dispossessed minority" whose fury is directed "implosively (...) each person against the other" (Young 1999, pp. 14, 21). Winlow and Hall (2013, p. 167) make a similar observation: "dissatisfaction and inarticulate rage gather in abundance in places of economic exclusion". The conditions of their area can encourage some young people to view their surroundings as "an adventure playground for them to demonstrate their personal resourcefulness and with good luck get rich" (Streeck 2016, p. 46). Young people tend to excel at resourcefulness, and every single young person has plentiful resources to offer: talents, abilities, personality traits, creative skills, capacities of every kind. But the adults, institutions and structures which hold power in these "adventure playgrounds" are not always adept at encouraging the deployment of those resources, or helping young people to recognise and enjoy their value, or at supporting young people to believe - to know - that they matter. Some, unfortunately, are better at encouraging a grinding sense of insignificance and alienation. Because of this, among other factors, a small minority of young people choose to mobilise a different kind of resource, violence, to achieve whichever instrumental or psychosocial goals matter to them. This has to change. 


\section{References}

Anderson, E., 2000. Code of the Street: Decency, Violence, and the Moral Life of the Inner City. New York: W.W. Norton.

Arendt, H., 1970. On Violence. New York: Harcourt.

Barker, J., et al., 2010. Pupils or prisoners? Institutional geographies and internal exclusion in UK secondary schools. Area [online], 42(3), 378-386. Available from: https://doi.org/10.1111/j.1475-4762.2009.00932.x [Access 3 November 2020].

Billingham, L., 2018. Hackney Wick Through Young Eyes: What local young people value, the problems they face, and what they want to change. London: Wick Award and Hackney Quest.

Billingham, L., and Irwin-Rogers, K., 2020. Mattering and the Violence in our Cities. In: R. Atkinson, ed., Urban Crisis, Urban Hope. London: Routledge.

Blazey, L., et al., 2017. Young people's capital of the world? [online]. Report. London Youth. March. Available from: http://londonyouth.org/wpcontent/uploads/2018/05/Young-peoples-capital-of-the-world-March-2017.pdf [Access 24 February 2019].

Bond, E., and Hallsworth, S., 2017. The Degradation and Humiliation of Young People. In: V. Cooper and D. Whyte, eds., The Violence of Austerity. London: Pluto, 75-84.

Bourdieu, P., 1979. Distinction. London: Routledge.

Bronfenbrenner, U., 1979. The Ecology of Human Development. Harvard University Press.

Broucek, F., 1979. Efficacy in Infancy: A Review of Some Experimental Studies and Their Possible Implications for Clinical Theory. International Journal of Psychoanalysis, 60, 311-16.

Butcher, M., and Dickens, L., 2016. Spatial dislocation and affective displacement: Youth perspectives on gentrification in London. International Journal of Urban and Regional Research [online], 40(4), 800-816. Available from: https://doi.org/10.1111/1468-2427.12432 [Access 3 November 2020].

Carr, R., Slothower, M., and Parkinson, J., 2017. Do Gang Injunctions Reduce Violent Crime? Four Tests in Merseyside, UK. Cambridge Journal of Evidence-Based Policing [online], 1(4), 195-210. Available from: https://doi.org/10.1007/s41887-017-0015-x [Access 3 November 2020].

Chiodo, D., et al., 2012. Longitudinal prediction and concurrent functioning of adolescent girls demonstrating various profiles of dating violence and victimization. Prevention Science [online], 13, 350-359. Available from: https://doi.org/10.1007/s11121-011-0236-3 [Access 3 November 2020].

Collins, R., 2008. Violence: A Micro-sociological Theory. Oxford: Princeton University Press.

Community Links, 2019. Community Conversations: Unearthing community-led ideas for tackling youth violence [online]. Canning Town: Community Links. Available from: https://www.community-links.org/wp-content/uploads/Community-LinksCommunity-Conversations-2018.pdf [Access 3 March 2019]. 
Contreras, R., 2013. The Stickup Kids: Race, Drugs, Violence and the American Dream. Berkeley: University of California Press.

Crouch, C., 2004. Post-Democracy. Cambridge: Polity Press.

Currie, E., 2016. The Roots of Danger. Oxford University Press.

De Zulueta, F., 2001. Violent attachments and attachment to violence. In: S.L. Bloom, ed., Violence: A Public Health Menace and a Public Health Approach. London: Karnac, 31-56.

Dorling, D., 2018. Peak Inequality: Britain's Ticking Time Bomb. Bristol: Policy Press.

Duckworth, J., 2002. Fagin's Children: Criminal Children in Victorian England. London: Hambledon \& London.

Ebner, J., 2019. Who are Europe's far-right identitarians? Politico [online], 4 April. Available from: https://www.politico.eu/article/who-are-europe-far-rightidentitarians-austria-generation-identity-martin-sellner/ [Access 10 May 2020].

Edwards, K.M., and Neal, A.M., 2017. School and community characteristics related to dating violence victimization among high school youth. Psychology of Violence, 7(2), 203-212.

Elliott, G.C., 2009. Family Matters: The Importance of Mattering to Family in Adolescence. West Sussex: Wiley-Blackwell.

Elliott, G.C., Colangelo, M., and Gelles, R.J., 2005. Mattering and Suicide Ideation: Establishing and Elaborating a Relationship. Social Psychology Quarterly [online], 68(3), 223-238. Available from: https://doi.org/10.1177/019027250506800303 [Access 3 November 2020].

Elliott, G.C., et al., 2011. Perceived mattering to the family and physical violence in the family by adolescents. Journal of Family Issues [online], 32(8), 1007-1029. Available from: https://doi.org/10.1177/0192513X11398932 [Access 3 November 2020].

Elliott, G.C., Kao, S., and Grant, A., 2004. Mattering: Empirical Validation of a SocialPsychological Concept. Self and Identity [online], 3(4), 339-354. Available from: https://doi.org/10.1080/13576500444000119 [Access 3 November 2020].

Ellis, A., 2016. Men, Masculinities and Violence. London: Routledge.

Flett, G., 2018. The Psychology of Mattering: Understanding the Human Need to be Significant. London: Academic Press.

Flett, G., et al., 2016. Antecedents, correlates, and consequences of feeling like you don't matter: Associations with maltreatment, loneliness, social anxiety, and the fivefactor model. Personality and Individual Differences [online], vol. 92, 52-56. Available from: https://doi.org/10.1016/j.paid.2015.12.014 [Access 3 November 2020].

Gaskell, C., 2005. Fighting for Respect: Youth, Violence and Citizenship in East London. Ph.D Thesis. Queen Mary, University of London.

Geuss, R., 2016. Reality and Its Dreams. London: Harvard University Press. 
Gill, K., Quilter-Pinner, H., and Swift, D., 2017. Making the Difference: Breaking the link between school exclusion and social exclusion [online]. October. London: Institute for Public Policy Research. Available from: https://www.ippr.org/files/201710/making-the-difference-report-october-2017.pdf [Access 10 March 2019].

Gilligan, J., 1997. Violence: Reflections on a National Epidemic. New York: Vintage.

Graeber, D., 2018. Bullshit Jobs: A Theory. London: Allen Lane.

Green, A., 2017. The Crisis for Young People. London: Palgrave Macmillan.

Groos, K., 1901. The Play of Man. Trans.: E.L. Baldwin. New York: Appleton.

Harding, S., 2014. The Street Casino: Survival in Violent Street Gangs. Bristol: Policy Press.

Harris, P., 2017. Inter-subjectivity and Worker Self-Disclosure in Professional Relationships with Young People: A Psychosocial study of Youth Violence and Desistance. The Howard Journal [online], 56(4), 516-531. Available from: https://onlinelibrary.wiley.com/doi/abs/10.1111/hojo.12229 [Access 3 November 2020].

Irwin-Rogers, K., 2019. Illicit Drug Markets, Consumer Capitalism, and the Rise of Social Media: A Toxic Trap for Young People. Critical Criminology [online], 27, 591-610. Available from: https://doi.org/10.1007/s10612-019-09476-2 [Access 3 November 2020].

Irwin-Rogers, K., Muthoo, A., and Billingham, L., 2020. The Youth Violence Commission Final Report [online]. Available from: http://yvcommission.com/final-report/ [Access 3 November 2020].

Irwin-Rogers, K., et al., 2019. Street gangs and urban violence in Europe. In: I. Vojnovic et al., eds., Handbook of Global Urban Health: The Metropolis and Modern Life. New York: Routledge, 484-508.

Jasko, K., Lafree, G., and Kruglanski, A., 2016. Quest for Significance and Violent Extremism: The Case of Domestic Radicalization. Political Psychology [online], 38(5), 815-831. Available from:

https://onlinelibrary.wiley.com/doi/abs/10.1111/pops.12376 [Access 3 November 2020].

Katz, J., 1990. Seductions of Crime: Moral and Sensual Attractions in Doing Evil. New York: Basic Books.

Kleinberg, B., and McFarlane, P., 2020. Violent music vs violence and music: Drill rap and violent crime in London. arXiv:2004.04598 [cs.SI] [online], 9 April. Available from: https://arxiv.org/abs/2004.04598 [Access 3 November 2020].

Kruglanski, A., et al., 2014. The Psychology of Radicalization and Deradicalization: How Significance Quest Impacts Violent Extremism. Advances in Political Psychology [online], vol. 35, suppl. 1, 69-93. Available from: https://doi.org/10.1111/pops.12163 [Access 3 November 2020].

Kulz, C., 2017. Factories for Learning. Manchester University Press.

Lalander, P., and Sernhede, O., 2011. Social mobilization or street crimes: two strategies among young urban outcasts in contemporary Sweden. EDUCARE, 2, 99-121. 
Lane, J., 2019. The Digital Street. New York: Oxford University Press.

Lauger, T., and Densley, J., 2018. Broadcasting badness: Violence, identity, and performance in the online gang rap scene. Justice Quarterly [online], 35(5), 816841. Available from: https://doi.org/10.1080/07418825.2017.1341542 [Access 3 November 2020].

Lewis, D.M., 2017. A matter for concern: Young offenders and the importance of mattering. Deviant Behavior [online], 38(11), 1318-1331. Available from: https://doi.org/10.1080/01639625.2016.1197659 [Access 3 November 2020].

Leys, C., 2003. Market-Driven Politics. London: Verso.

Lunghy, E., et al., 2019. Insiders Looking Out: Solutions to Youth Violence from People who have Lived it. London: The Winch.

Lynes, A., Kelly, C., and Kelly, E., 2020. Thug Life: Drill Music as a Periscope into Urban Violence in the Consumer Age. The British Journal of Criminology [online], 60(5), 1201-1219. Available from: https://doi.org/10.1093/bjc/azaa011 [Access 3 November 2020].

Marshall, S.K., 2004. Relative contributions of perceived mattering to parents and friends in predicting adolescents' psychological wellbeing. Perceptual and Motor Skills [online], 99(2), 591-601. Available from: https://doi.org/10.2466/pms.99.2.591-601 [Access 3 November 2020].

Marx, K., 2000. Economic and Philosophical Manuscripts. In: D. McLellan, ed., Karl Marx: Selected Writings. Oxford University Press, 83-121. (Originally published in 1844).

May, R., 1998. Power and Innocence: A Search for the Sources of Violence. New York: Norton.

Mishra, P., 2018. Age of Anger. Harmondsworth: Penguin.

Raque-Bogdan, T.L., et al., 2011. Attachment and Mental and Physical Health: SelfCompassion and Mattering as Mediators. Journal of Counselling Psychology [online], 58(2), 272-278. Available from: https://doi.org/10.1037/a0023041 [Access 3 November 2020].

Rosenberg, M., and McCullough, B.C., 1981. Mattering: Inferred significance and mental health among adolescents. Research in Community \& Mental Health, 2, 163182

Schieman, S., and Taylor, J., 2001. Statuses, Roles, and the Sense of Mattering. Sociological Perspectives, 44(4), 469-484.

Schlossberg, N., 1989. Marginality and mattering: key issues in building community. New Directions for Student Services [online], 48, 5-15. Available from: https://doi.org/10.1002/ss.37119894803 [Access 3 November 2020].

Schumaker, J., 1997. Religious Motivation Across Cultures. In: D. Munro, J.F. Schumaker and S.C. Carr, eds., Motivation and Culture. London: Routledge, 193209. 
Sharpe, J., 2016. A Fiery and Furious People: A History of Violence in England. London: Penguin.

Stanfield, L., 2018. Mattering: Foundations for Flourishing Lives. London: Claremont Project.

Storrod, M., and Densley, J., 2017. "Going viral" and "Going country": The expressive and instrumental activities of street gangs on social media. Journal of Youth Studies [online], 20(6), 677-696. Available from: https://doi.org/10.1080/13676261.2016.1260694 [Access 3 November 2020].

Streeck, W., 2014. Buying Time: The Delayed Crisis of Democratic Capitalism. London: Verso.

Streeck, W., 2016. How Will Capitalism End? London: Verso.

Sullivan, M.L., 2005. Maybe we shouldn't study "gangs": Does reification obscure youth violence? Journal of Contemporary Criminal Justice [online], 21(2), 170-190. Available from: https://doi.org/10.1177/1043986204272912 [Access 3 November 2020].

Taylor, J., and Turner, J., 2001. A Longitudinal Study of the Role and Significance of Mattering to Others for Depressive Symptoms. Journal of Health and Social Behavior [online], 42(3), 310-325. Available from: https://doi.org/10.2307/3090217 [Access 3 November 2020].

Thapar, C., 2019. Don't censor drill music, listen to what it's trying to tell us. The Guardian [online], 6 February. Available from:

https://www.theguardian.com/commentisfree/2019/feb/06/dont-censor-drillmusic-listen-skengdo-am [Access 3 November 2020].

Vigil, J.D., 1988. Group processes and street identity: Adolescent Chicano Gang Members. Ethos [online], 16(4), 421-445. Available from: https://doi.org/10.1525/eth.1988.16.4.02a00040 [Access 3 November 2020].

Vigil, J.D., and Yun, S.D., 1998. Vietnamese Youth Gangs in the Context of Multiple Marginality and the Los Angeles Youth Gang Phenomenon. In: K. Hazlehurst and C. Hazlehurst, eds., Gangs and Youth Subcultures: International Explorations. New Brunswick: Transaction.

Wacquant, L., 2007. Urban Outcasts: A Comparative Sociology of Advanced Marginality. Cambridge: Polity Press.

Winlow, S., and Hall, S., 2013. Rethinking Social Exclusion: The End of the Social? London: Sage.

Young, J., 1999. The Exclusive Society. London: Sage. 